to prepare for rapid tracheotomy and to then adopt the latter course. I succeeded in removing over one-half of the growth with the forceps, and thus averting the immediate danger of asphyxiation. Now while I appreciate all the advantages mentioned by the previous speakers in favor of the galvanocautery, I doubt if I shall be successful in reaching the remainder of the growth with the cautery, owing both to the age of the patient, who is a boy six years of age, and to the location of its attachment, and I am inclined to believe that I will stand better chances of reaching it with schrotter's forceps.

\section{ORBITAL AND OCULAR GROWTHS.}

REPORT OF FOUR CASES WITH TWENTY-TWO PHOTOMICROGRAPHIC ILLUSTRATIONS.

Read in the Section of Ophthalmology at the Forty-third Annual Meet ing of the American MedicaI Association, held at Detroit, Mich., June, 1892.

\section{BY JOSEPH A. WHITE, A.M. M.D.,}

SENIOR SURGEON TO TIE RICHMOND, VA., EYE, EAR, THROAT AND NOSF IN FIRMARY.

AND WM. M. GR IY, M.D.

PATHOLOGIST OF TIIE ARMY MEDICAL MUSEUM, WASHINGTON, D. C.

I present these cases of tumors of the eye and orbit from my clinic at the Richmond,Va., Eye, Ear \& Throat Infirmary operated on during this year, 1892 , because I thought they were of sufficient interest for consideration. One is a case of melanotic sarcoma of the choroid that has as yet had no recurrence, but as this character of tumor is metastatic, there may be some manifestations of the same kind of growth elsewhere. The second is a sarcoma of the orbit which recurred twice after the original growth and eye were removed. The other two were growths of the orbit intimately connected with the perioste um; one in a woman 58 years of age, the other in a girl 16; one from the inner side of the orbit, extending from the orbital edge back and behind the eye to the sphenoidal fissure, the other from the external side following the same direction, and producing an apparently similar pathological condition of the eye and its annexes. Cases one and three were operated on by myself; cases two and four by Dr. John Dunn, Chief of Clinic at the Infirmary.

Case 1. Melanotic Sarcoma of the Choroid-Geo. W. Wingfield, aged 54 years consulted me first, May 30,1890. The left eye was blind, slightly exophthalmic, tension increased, the cornea clouded, the anterior chamber abolished, and the whole upper and outer part of the sclerotic of a dense black color. I diagnosed melanotic growth of the eye, and advised enucleation. This he declined to have done, and went home. I heard nothing from him until February 6, 1892 , when he presented himself at my office with the eye so enormously enlarged that the lids could not be closed over it, the whole of the sclerotic perfectly black; patient suffering constant and excruciating pain. I gave him the same advice as before, and he consented to the removal of the eye. As cocaine had very little effect in anæsthetizing the eye, I gave chloroform, althogh I rarely have recourse to anything but cocaine in enucleation, and removed the globe. It was so distended, I was obliged to split the outer canthus to get it out of the orbit. Fearing the growth extended backward along the optic nerve sheath I grasped the nerve with a stout pair of fixation forceps before I cut the eye loose, so as to draw it out, and remove as much of it as possible. This I did after enucleating the eye, drawing the nerve out with the forceps already in position as far as possible, then putting another pair behind them and pulling again hand over hand as it were, and in this way I cut off about three-quarters of an inch of the nerve.

The eye was placed in Muller's fluid and sent to Dr. Wm. M. Gray, pathologist of the Army Medical Museum in Washington, and $I$ append his report of the condition of the eye. I saw this patient on May 30 when the socket was clean and no signs of recurrence. I inserted an artificial eye and he returned home.
Dr. Gray sent me the following report of his examination of the eye; with the accompanying photographic plates and microscopic slides, both prepared by him in his laboratory.



SPECIMEN A.-Fig. 1. Large round and large
sarcoma of eye; developing from choroid coat.

Fig. 1. Shows a longitudinal antero-posterior section through the entire eyeball, and its contained tumor.

The tumor is composed of two seemingly distinct masses; one an intensely pigmented growth forming the peripheral portion, and a central mass, which is very slightly pigmented The outer pigmented portion is made up of large round, spindle and stellate pigment cells, with a few small

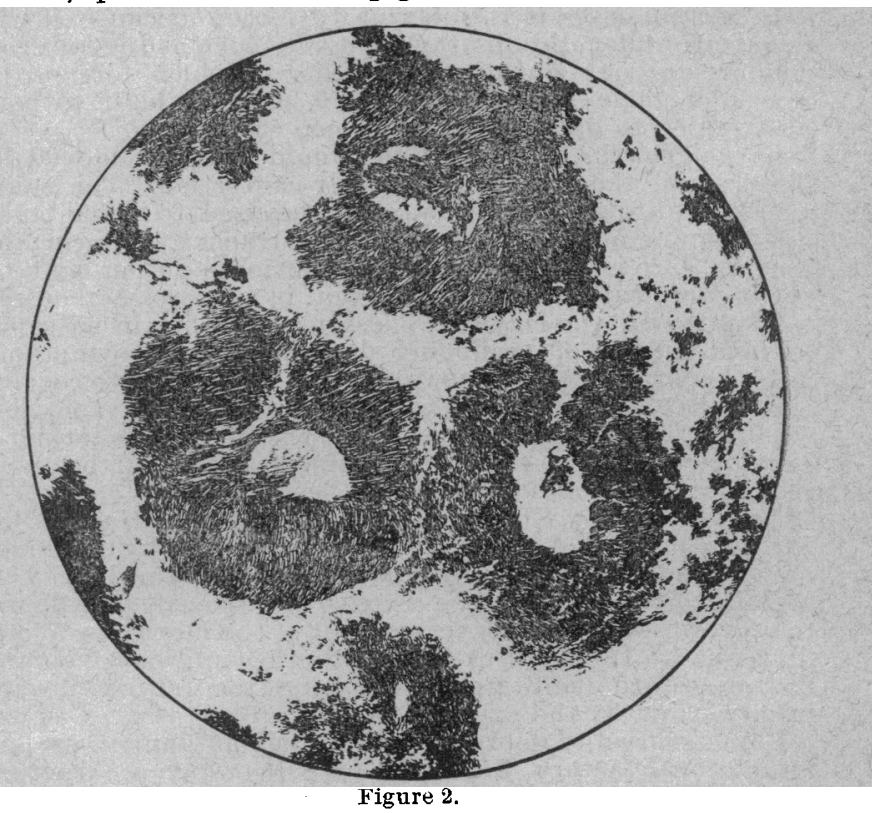

round unpigmented cells. The slightly pigmented central portion of the growth is composed of large round cells, somewhat epitheloid in appearance, and large spindle cells arranged in circular masses around small blood vessels; the walls of these blood-vessels are quite thick, and are composed of dense fibrous connective tissue. Fig's 2 and 3 show the circular cell masses in the slightly pigmented portion.

Fig. 4. one of the circular cell masses on the border of the dense pigment portion. Fig. 5 shows the large round cells composing the greater portion of the entire growth; it is taken on the border of the densely pigmented portion, and contains a number of large round pigment cells. Fig. 6 from the same locality shows the same cells with an irregu- 
lar shaped large spindle pigment cell, and several pigment masses. Fig. 7 shows the large spindle cells composing a portion of the central unpigmented circular cell masses. The greater portion of the sclerotic coat is obliterated by the pigmented growth with which it is infiltrated, and shows in several places the growth passing out into the orbit. Fig. 8. The retina has entirely disappeared.

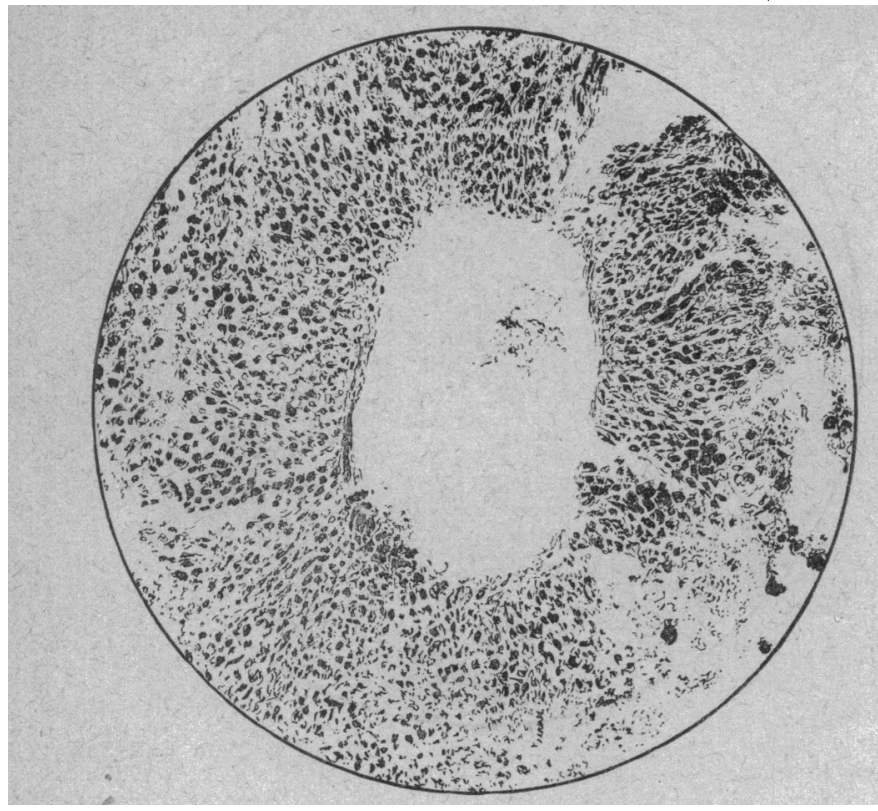

Figure 3.

Case 2.-Malignant Growth of the Orbit--(Report given me by Dr. Dunn.) The patient, a full-blooded negro, aged 19 years, came Nov. 6,1890 , to the clinic of the Richmond Eye, Ear and Throat Infirmary. He had a growth protruding from between the lids of his left eye. This growth had made its appearance about nine months before, the patient being then 181/ years of age. The negro said that in July, 1890, the growth had been partially removed, not entirely, for he had been told that a small piece of it still remained. Since



Figure 4 .

July the tumor had grown so rapidly that the day the negro came to the clinic it completely filled the inter-palpebral space, and the eye ball could be seen only by raising the upper lid. Examination of the tumor showed that it consisted of two parts, an encapsulated central part and its prolongations along the conjunctiva and subjunctival tissue of the lower cul-de-sac. The encapsulated portion was about the size of a hickory nut, and projected from the orbit below the eye ball, which it pressed upward and backward, and the movements of which it greatly hindered. The lower half of this central part protruded from between the lids and pressed so firmly against the inner canthus that the caruncle could not be seen. The prolongations from the surface of the main body of the growth had completely filled the lower cul-de-sac of the conjunctiva to within a few $\mathrm{mm}$. of the outer canthus.

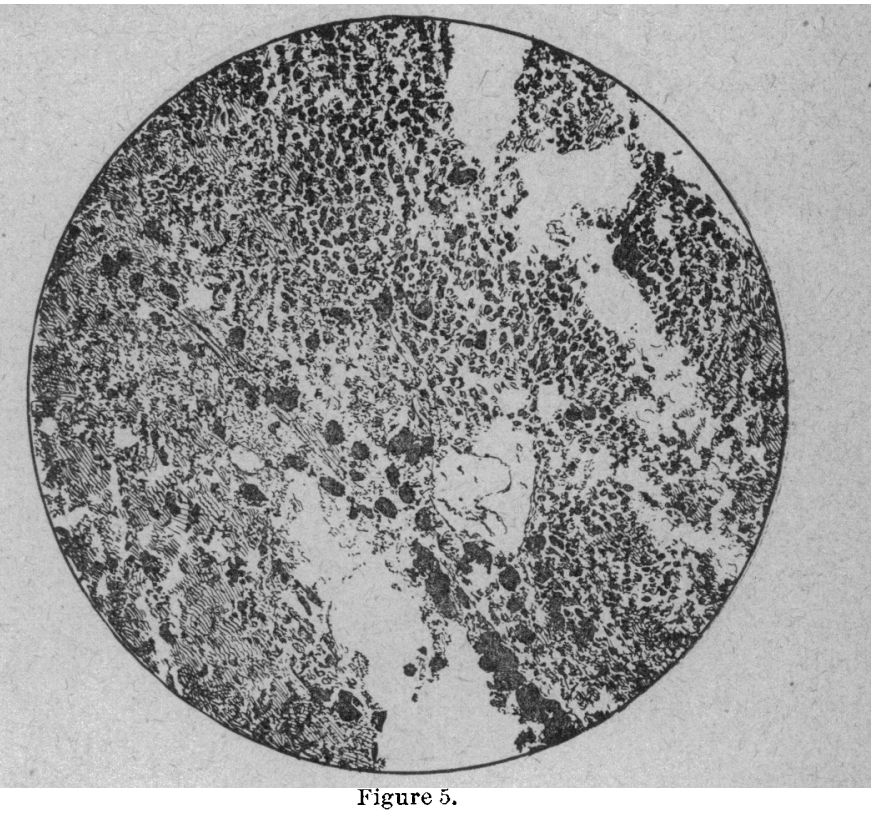

The eye ball was perfectly healthy; so was the upper half of the ocular conjunctiva and the conjunctiva below immediately adjacent to the cornea. Centrally below, however, were seen running from the tumor to the edge of the cornea perhaps half a dozen small blood-vessels; these were all within a space of $6 \mathrm{~mm}$. breadth. The surface of the tumor was red, rough, and, in places, warty, and was covered with a copious, dirty, purulent secretion. The tumor, though not

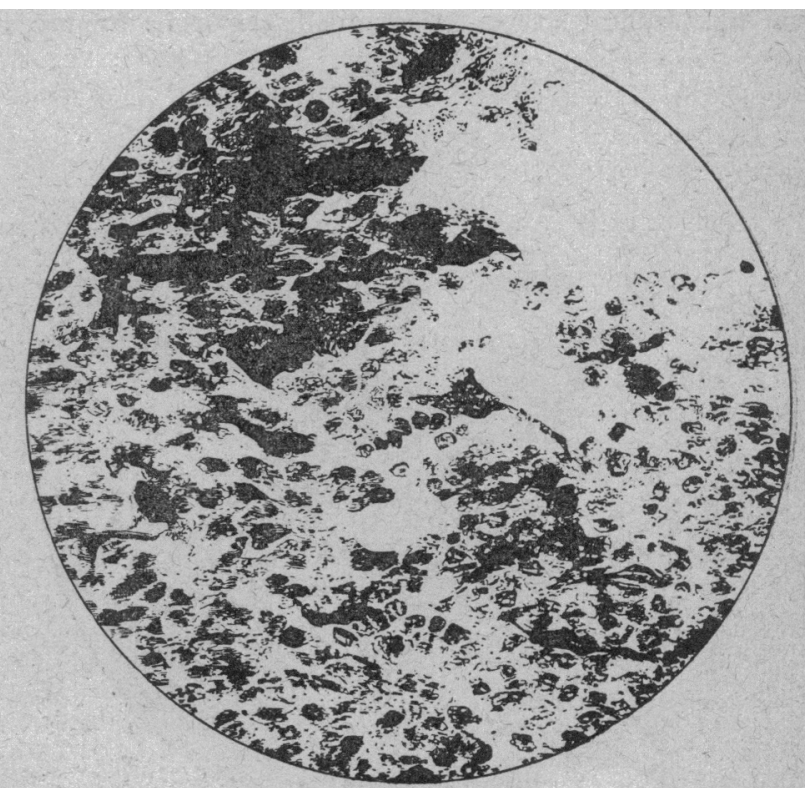

painful in itself, was very sensitive to the least pressure, ven when made through the lids.

Under cocaine, a small portion of the tumor was removed for microscopic examination, and patient was told to return in two days. The microscopic examination was unsatisfactory.

On Nov. 8 , the patient returned. The growth was perceptibly larger than it was two days before, and I proceeded to remove it. An external canthotomy was done; then $t h$ 
conjunctiva of the upper half of the ball was cut as in an enucleation, and the tendons of all the muscles, except the inferior rectus were cut. The nerve was next severed, and then the eye and the tumor were turned of the orbit from above, after which no trouble was had in removing the growth in what seemed its entirety. The main body of the tumor had the following measurements: From above down-

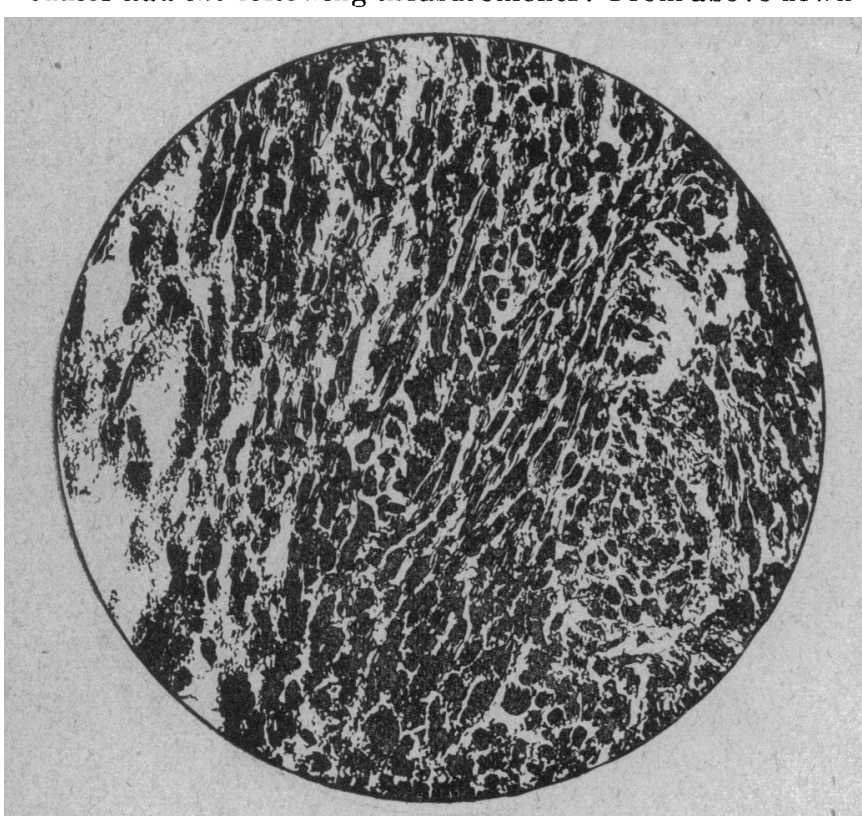

Figure 7 .

ward, $32 \mathrm{~mm}$., length $25 \mathrm{~mm}$., from before backward, $15 \mathrm{~mm}$.

The negro, who was a sailor, came to the clinic to have his eye dressed only for four days, after which time he joined his vessel.

He returned in January 1892. Up to January 1, there was no return of the tumor. It began to reappear early in this month, and by the 21st, it was two-thirds the size of a lemon, filling entirely the orbit, and protruding in a large mass from it. It was immovable in the orbit. Removed

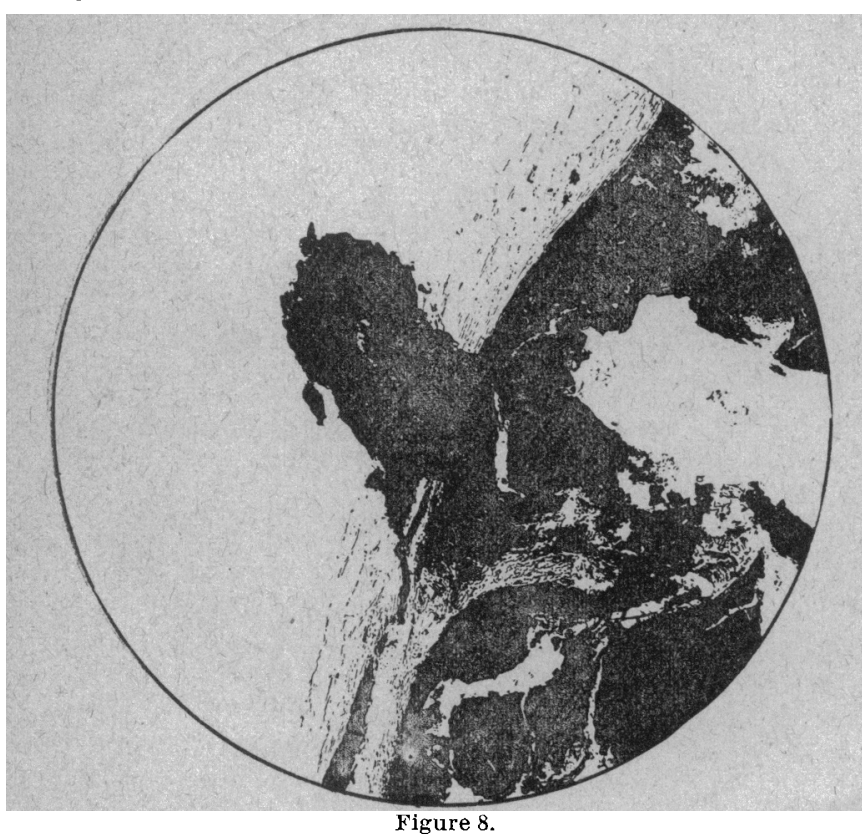

under chloroform. Found to have for the most part, a firm capsule, which was adherent to the eyelids, and everywhere to the walls of the orbit, even as far back as the entrance of the optic nerve. Iarge portions of the periosteum of the orbit stripped off in attempt to remove tumor. Orbit cleaned out. There were several sacs present in the tumor. Rupture of one showed it to be filled with thick cellular juice. Diagnosis, fibro-cystic sarcoma. Wound healed by remains of lid adhering to walls of orbit as far back as possible. No return up to May $30,1892$.

The growth was also sent to Dr. Gray, who gives the following report with illustrations.

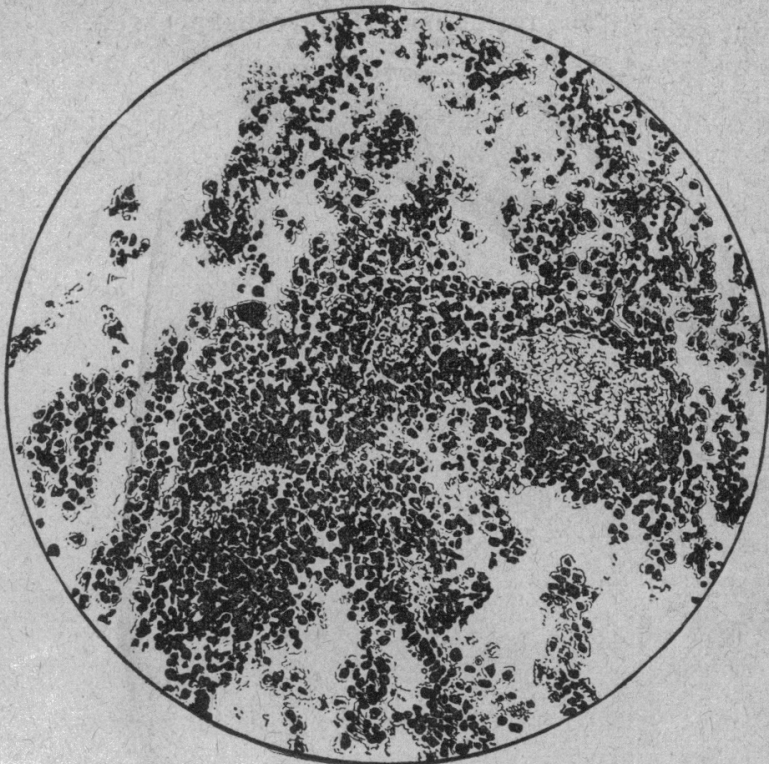

Specrmey B.-Fig, 9.-Small and Large Round Cell, Giant Cell Saroma of Orbit.

This growth is composed of round cells of various sizes; the larger cells have a very close resemblance to epithelial cells; in number the smaller cells predominate. Scattered through the cell mass are numerous typical giant cells, also some large round or irregular shaped cells, with multiple nuclei, which have not the characteristic appearance of giant cells, being almost entirely lacking in cell protoplasm.

There is very little intercellular tissue in the growth, no distinctly formed fibrous intercellular tissue, the cells seem to be connected by a finely granular material.

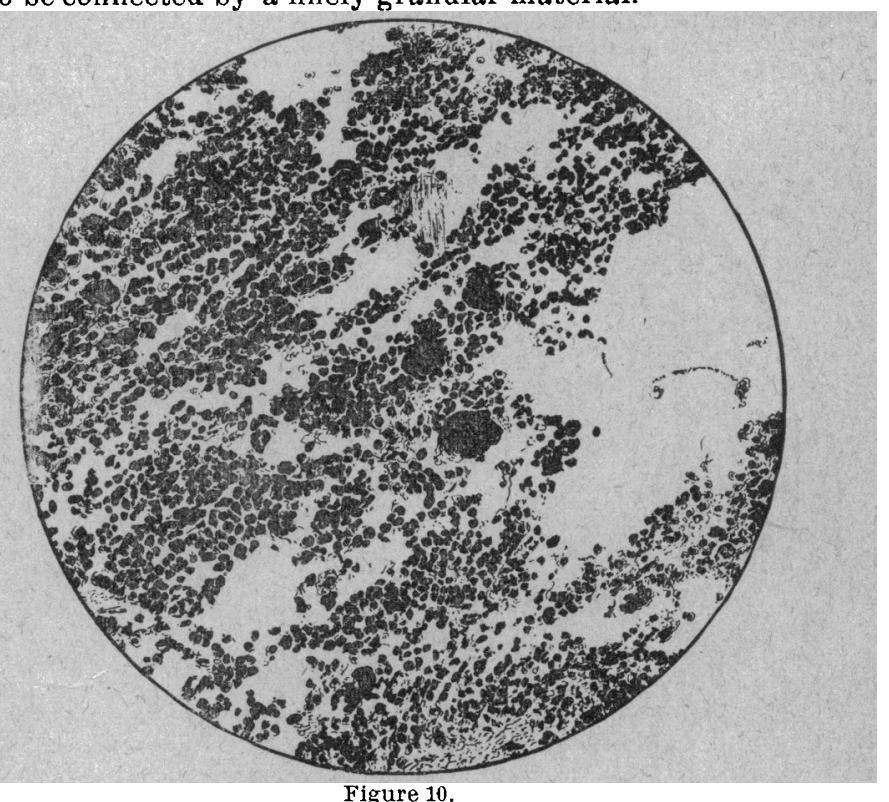

The growth is quite vascular, some of the blood vessels have distinct fibrous walls, others are mere channels between the cells as shown in Fig. 9. Fig's. 10 and 11 of the same field show the round cells composing the body of the tumor, with a group of three giant cells. Fig. 12 shows several of the irregular shaped cells composed of multiple nuclei with a minimum of cell protoplasm.

Case 3.-Fibroma of the Orbit.-Mrs. S. C. Robinette, 58 years of age, of Crewe, Va., consulted me on February 15, 1892. She had been suffering great pain in the left side of her face for about three months, especially under and to the na- 
sal side of the eye. It was thought at first that she had some trouble of the antrum. When I saw her the eye was tilted upwards, slightly exophthalmic, motion downwards was impeded, the inferior rectus being paretic, and there was pain on pressure over the inner and lower orbital edge. The vision was $20-30$ with $+1 D$. The refractive media were clear, but the optic nerve was engorged resembling "Stauung's papilla."

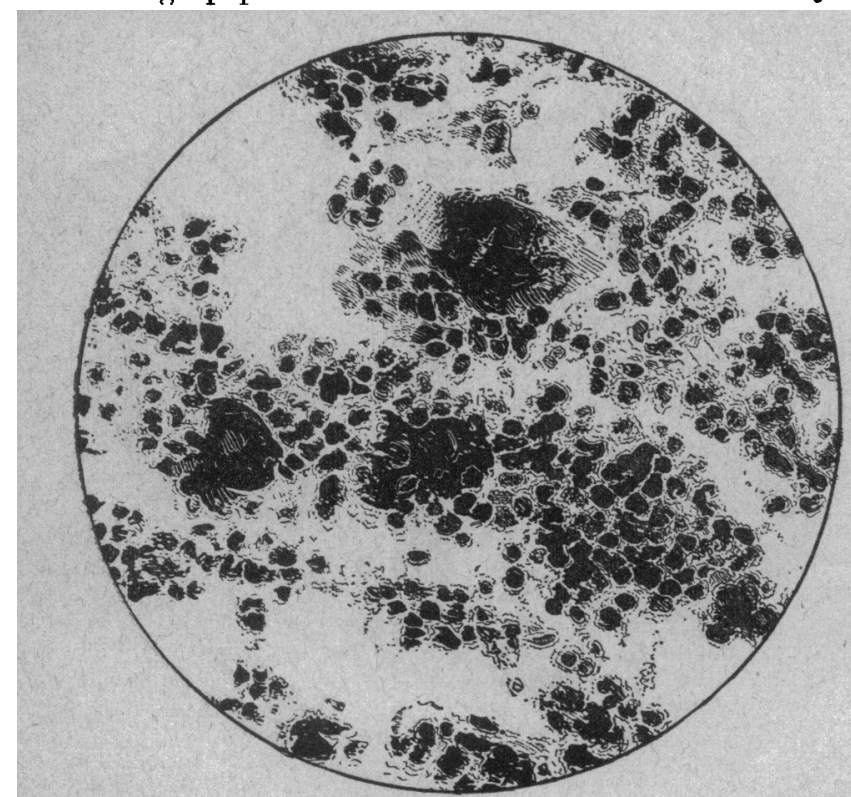

Figure 11.

By pushing the eye up and out and making firm pressure down and backwards under it at the inner orbital edge, a well marked projection be felt on the wall of the orbit. On the 16th, I exposed the orbital edge by an incision through the lid and attempted to remove the growth without enucleating the eye. I found it projected too far back in the orbit to do this successfully, and as I had not asked her permission to remove the eye, which was perfectly good as above shown, I contented myself with taking away as much of the growth as I could and sent it to Dr. Gray for examination

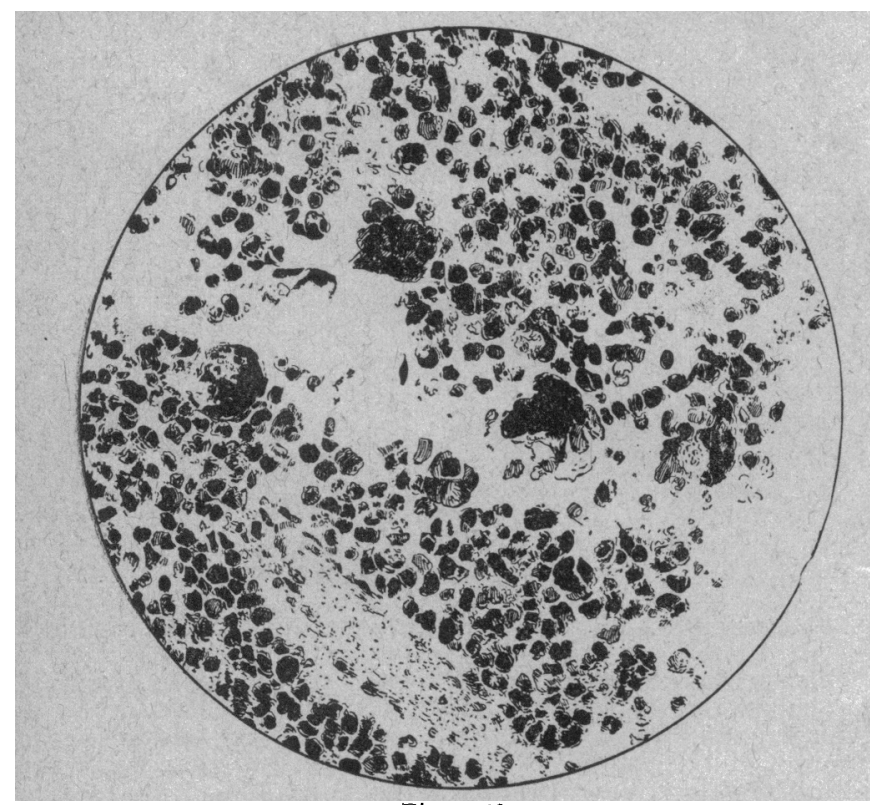

Figure 12.

He reported it was composed of fibrous tissue, was not malignant, but thought the eye ought to removed, so as to thoroughly enucleate the remains of the growth. On March 29, I again operated by removing the eye and tumor as far back as I could. 1 found it extended to the sphenoidal fissure and possibly passed into the cranial cavity, as I am satisfied I simply amputated the growth at the bottom of orbit instead of removing it in toto. I sent this also to $\mathrm{Dr}$ Gray and asked him to make a report and give me sections I also sent the eye, thinking it might prove valuable for miscroscopic examination, being almost normal. I saw the patient again on April 27 and found no signs of the tumor in the orbit. Whether she will have a recurrence I cannot say with certainty, but think it probable.

Dr. Gray reported as follows, sending photos to illustrate his report:

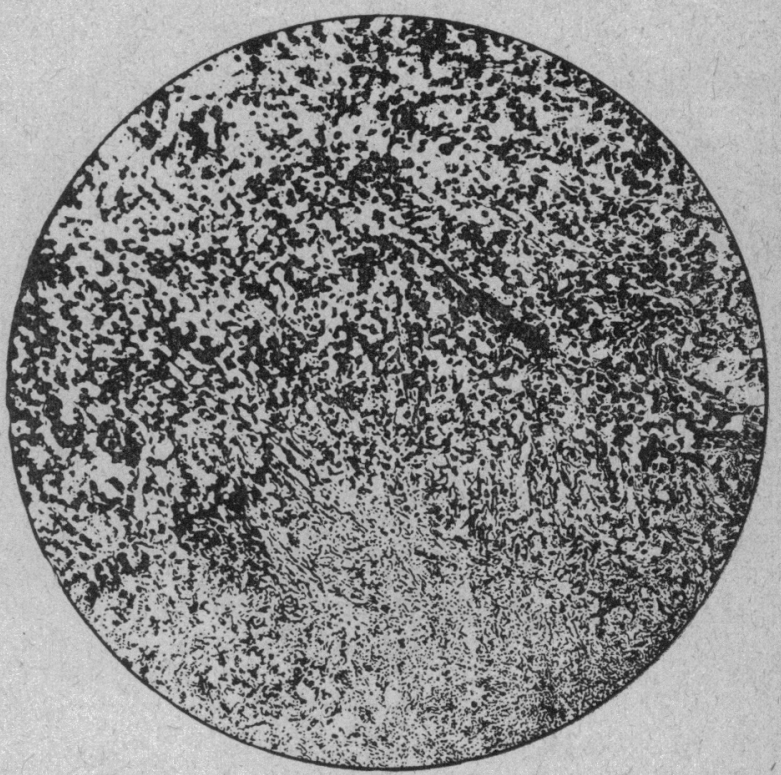

SPECiMen C.-Figure 13,-Soft Fibroma of Orbit.

This growth is made up of two portions; a central zone composed of very fine dense fibres, which have undergone some degeneration, probably due to pressure, and an outer zone composed of small and large bands of dense fibrous connective tissue running in all directions; the connective tissue of the outer zone is very rich in nuclei and very vascular; the nuclei are composed of small round and small spindle cells. Some of the blood-vessels of the outer zone have well formed walls, but the majority are simple chan-

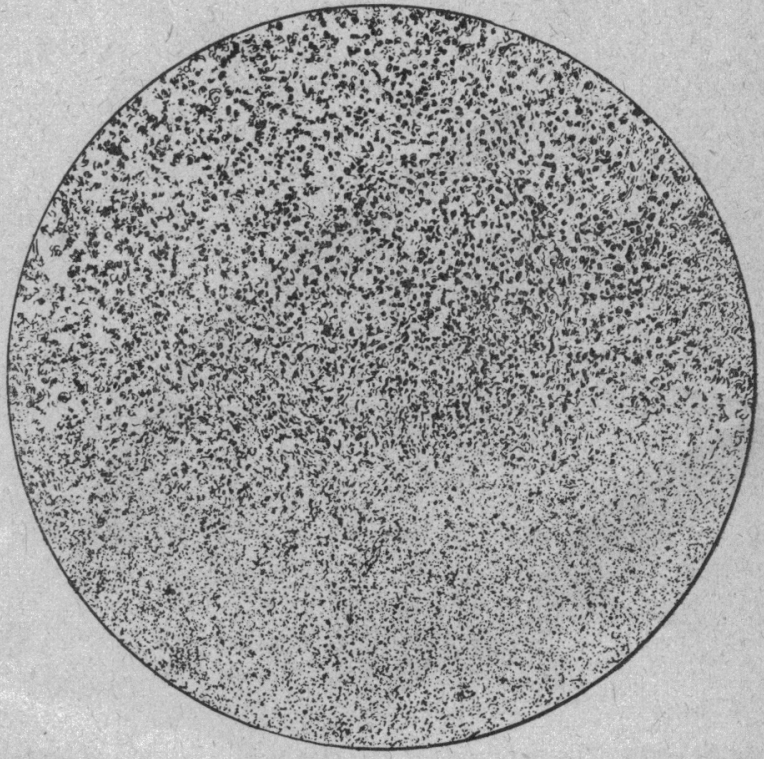

Figure 14.

nels, well defined, with sometimes a single layer of cells forming their walls. Figures 13 and 14 show portions of the central and outer zones. Figures 15 and 16 show the richly nucleated fibrous outer zone, with the small blood channels. Figure 17 shows a very richly nucleated portion with two of the larger blood channels, whose walls are ormed by a single layer of cells. 
Case 4.-Tuberculous Growth of Orbit.-(Report given me by Dr. Dunn.) Mary, aged 16, first had eye trouble in August, 1891, no clear history of course but probably traumatic. First seen in May, 1892. Protrusion of left eye, apparent paralysis of left upper lid. Tangent to cornea O. $\mathrm{S} .7 \mathrm{~mm}$., in advance of tangent to anterior surface of cornea of $0 . D$. Movement of the eye impeded in all directions. Diplopia

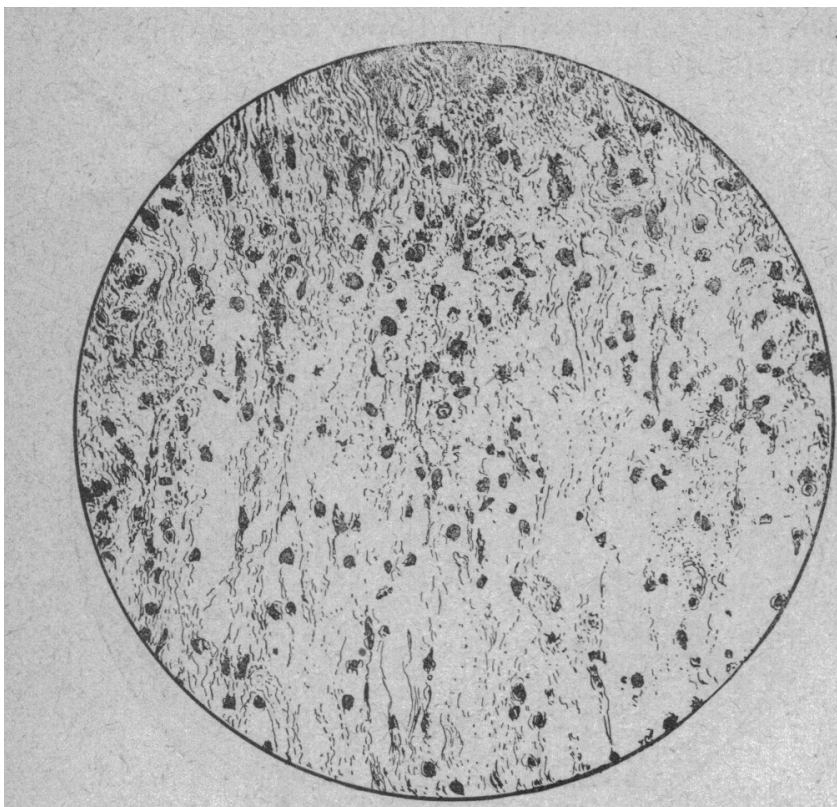

Figure 15.

when patient looks to the left. $V .=20-30$. No inflammatory symptoms, overfilling of vessels over the insertion of external rectus $\mathrm{O}$.S. No pain upon pressure upon ball. Severe neuralgic attacks about the eje. Just below external angle of the orbit, contiguous with the bone can be felt a hard, firm though perhaps slightly elastic, immovable growth, which extends back into the orbit. The width and thickness of the portion of the growth that can be felt is

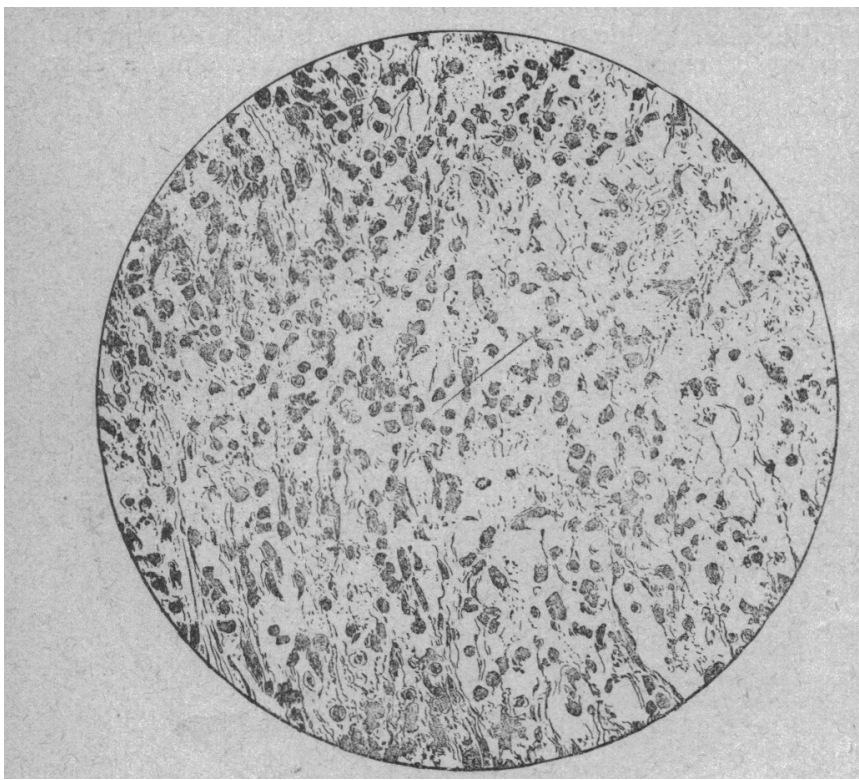

Figure 16

about that of a lead pencil. To the touch, so hard, incompressible and immovable was this part of the growth, that it suggested osteoma.

In no degree painful on pressure. Operation, outer canthus split. Vertical downward incision, about 1 inch; flap held back with a thread. Tumor found adherent to the edge of the orbit, and to the periosteum of the orbital plates of the malar, superior maxilla and sphenoid. Origin near entrance of optic nerve into orbit; but not from optic fibrous sheath. Adherent to external rectus. Eye saved; vision good. Wound healed by first intention. Probably internal squint, due to cutting the external rectus.

This growth was peculiar in shape. It resembled a small pear which had been compressed, the base at the orbital edge, the apex and stem far back in the orbit. It was about three quarters of an inch wide at the base and tapered to a

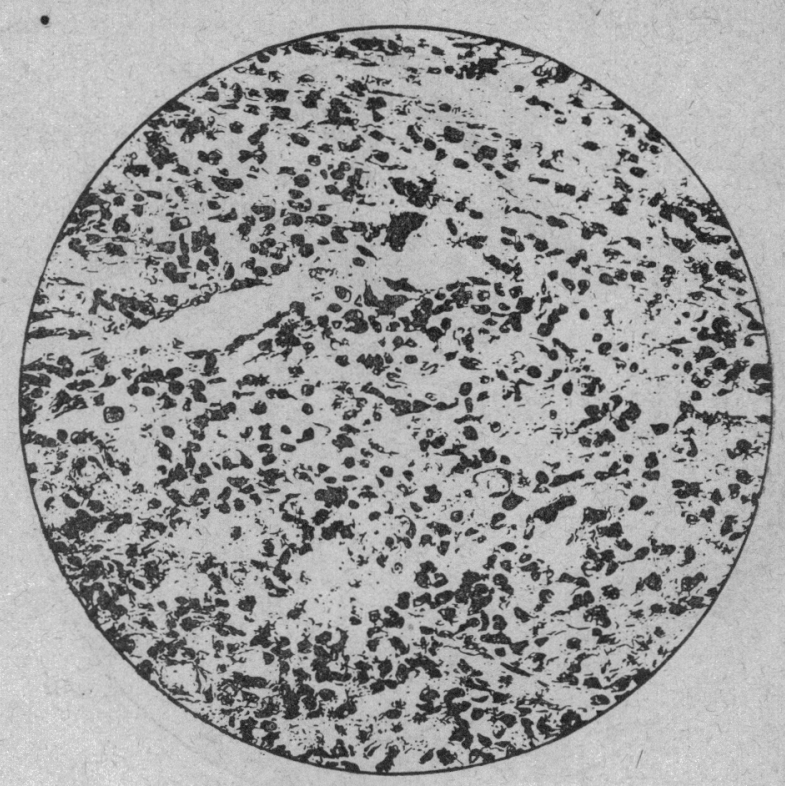

Figure 17.

point with a long cord-like projection about three quarters of an inch long. The length of the growth itself was more than an inch. It was sent to Dr. Gray who gave me the following interesting report:

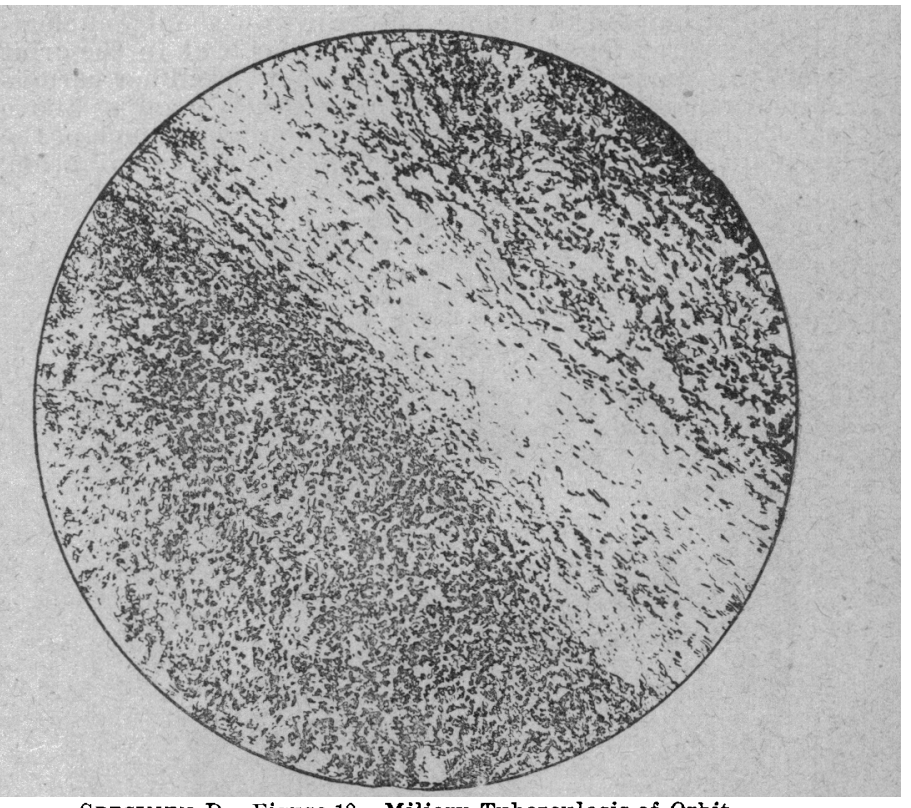

SPECIMEN D.-Figure 18.-Miliary Tuberculosis of Orbit.

This specimen is composed of bands of very dense fibrous connective tissue; between the fibrous bands is an extensive lymphoid infiltrate, while throughout the tissue are numerous aggregations of these cells, forming nearly typical miliary tubercles. These cell aggregations differ from the typical tubercles in not containing giant cells. The tissue contains giant cells however, but they are only found far removed from the tubercles among the cells infiltrating the fibres.

Repeated attempts at staining failed to demonstrate tubercle bacilli in the tissue.

Fig's. 18 and 19 show the lymphoid infiltrate between the connective tissue fibres. 
Fig. 20 shows two of the cell aggregations forming the socalled miliary tubercles.

Fig. 21 one of the tubercles more highly magnified

Fig. 19 also shows two giant cells imbedded in the infiltrating cells.

Fig. 22 one of the giant cells more highly magnified.

In case 1 the grow th seems to have started from the ciliary body between the superior and external rectus,

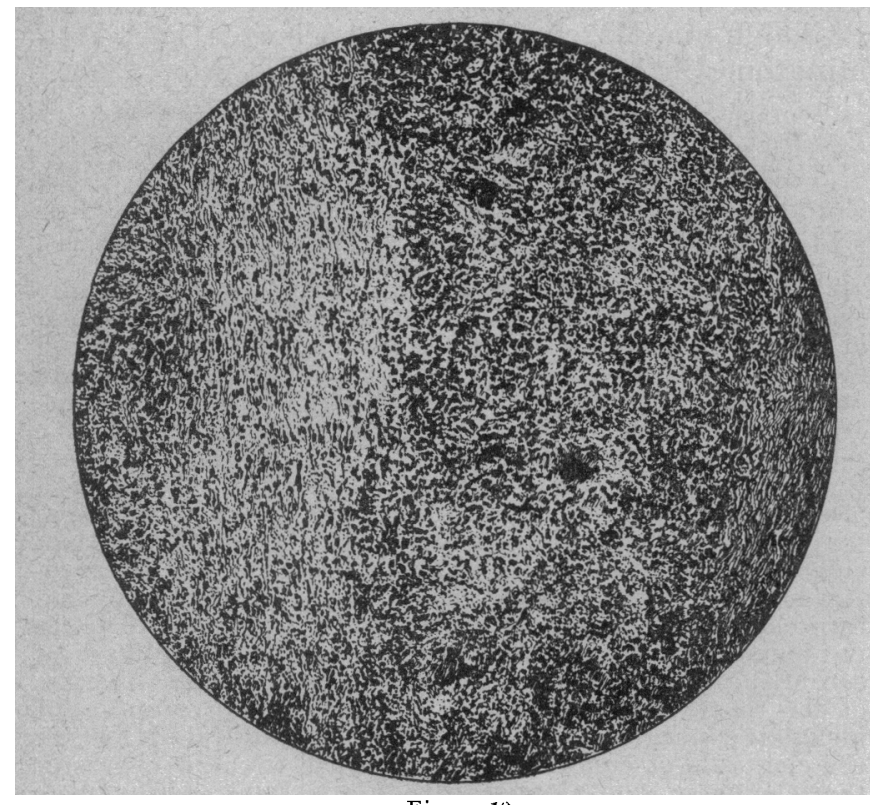

Figure 19.

and gradually involved other portions of the uveal tract, but at no time did it perforate the coats of the eye, as far as could be determined macroscopically, but the microscope shows it had extended through the sclerotic. As a melanotic tumor is among the rarer forms of intraocular growths I considered it of sufficient interest to present here.

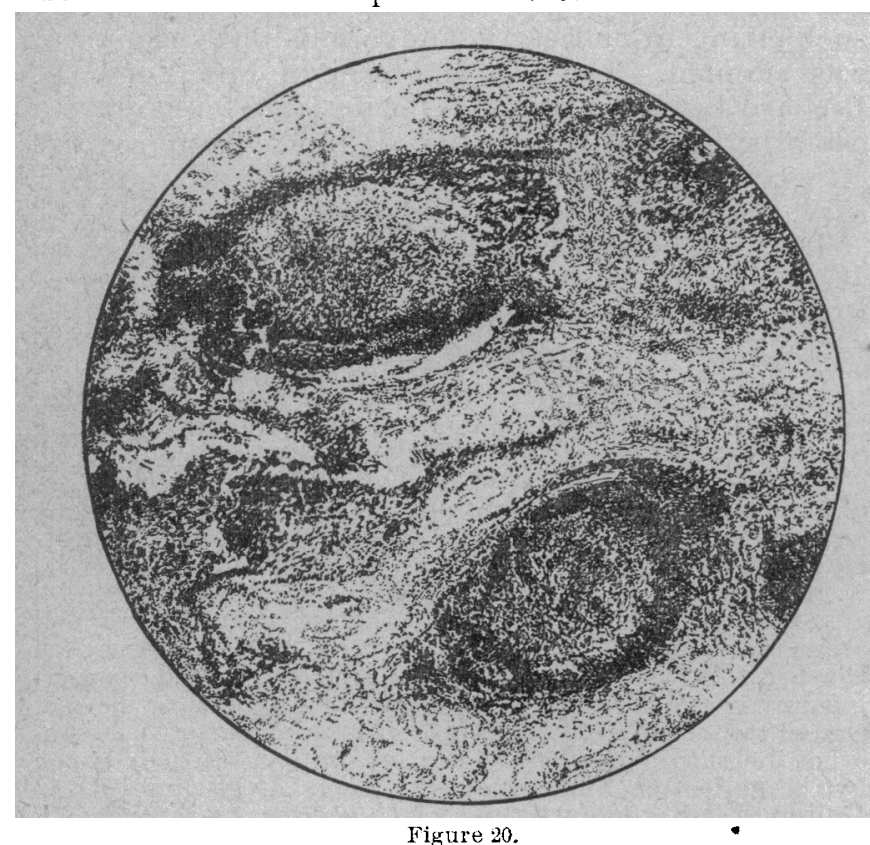

Case 2 was seen at too late a stage of the development of the neoplasm to determine its point of origin with certainty, but it probably developed in the subconjunctival tissue below the eyeball, as even when the enucleation became imperative, the eye was perfectly healthy, and the tumor had no attachments to the latter except by a band of tissue miting it to the sclero-corneal margin. It was a purely extraocular growth, developing in the loose subconjunctival tissue and enveloped in a dense connective tissue capsule, which whilst connected with the orbital walls completely isolated the tumor from the deep orbital tissues.

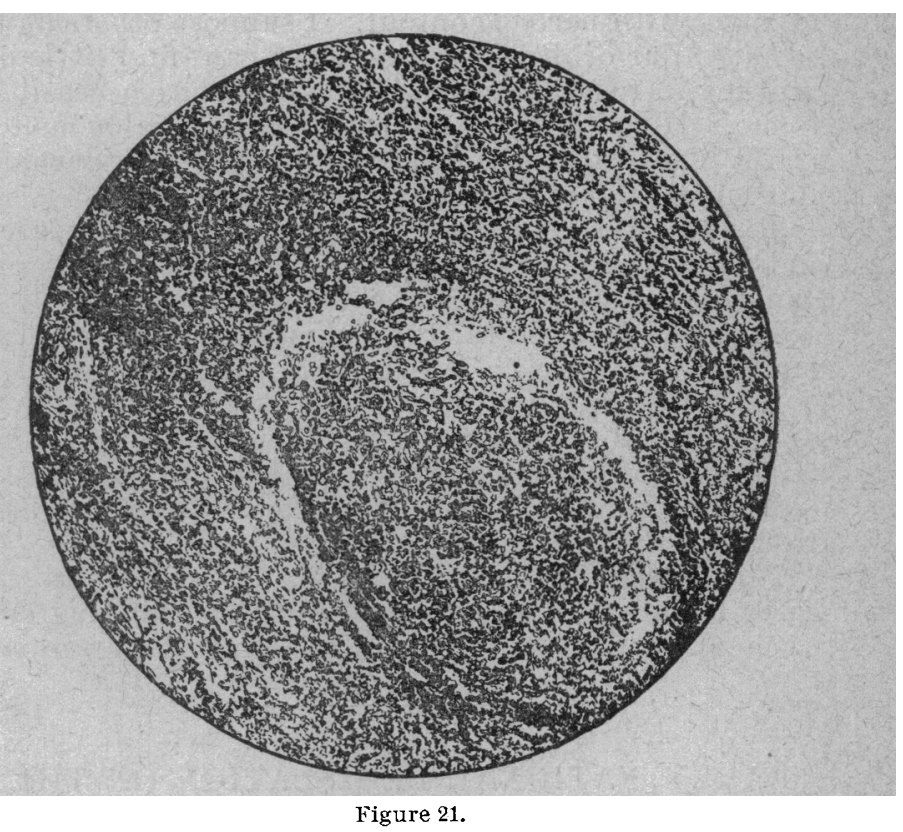

Case 3 is of interest from the fact that it was fibroid apparently originating from the orbital portion of the superior maxilla, as this was the only point of close attachment, except at the bottom of the orbit, where it seemed attached to the sphenoid, if it did not pass into the cranial cavity.

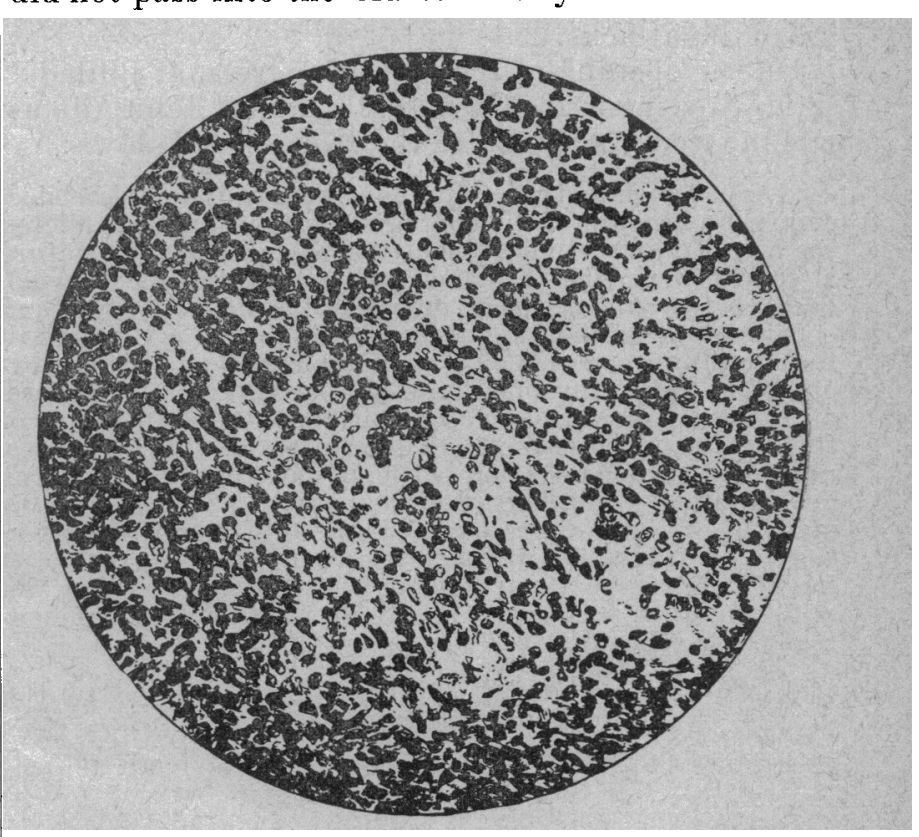

Figure 22,

There was no evidence of its originating from any of the neighboring cavities, and had no attachments to any of the contiguous bony structures.

Case 4, a tuberculous growth as reported by Dr. Gray, was to me different from any orbital tumor I 
had ever seen. Its point of origin could not be determined, but it seemed firmly attached to the outer and lower orbital wall, and after its marginal adhesions had been freed, it was easily enucleated with knife handle and finger. I assisted Dr. Dunn in the operation, and I found little trouble in tearing up the attachments, after I was able to get my finger behind it. It seemed to be encapsulated and came away solidly and with perfect contour. I suppose others have seen similar orbital growths, but I can find little or nothing in regard to them in the literature accessible to me. How a growth microscopically analogous to, if not identical with miliary tubercle could develop in such a subject, I do not understand.

The girl is an exceptionaly stout, sturdy, hearty individual with no signs of disease of any other organ, a picture of perfect health.

This fact and the rarity of this form of orbital tumor makes the case a particularly interesting one.

In conclusion, I wish to express my appreciation of Dr. Gray's excellent work in his part of this contribution to the proceedings of the Section, as without his help my record of these cases would have had little interest.

I have also to thank Dr. Dunn for writing up the cases he operated on at the clinic, especially as one of them, case 4 , is the most interesting one presented.

\section{EARLY NATIONAL LEGISLATION ON THE SUBJECT OF QUARANTINE. BY STEPHEN SMITH, M.D., OF NEW YORK. \\ (Concluded from page 412.)}

During the summers of 1796 and 1797 the yellow fever again prevailed widely and increased the public alarm by the extension of its area and the fatality of its attacks.

On the opening of the Fifth Congress, at Philadelphia, November 23, 1797, the President, John Adams, commenced his speech to the Houses as follows:

"I was for some time apprehensive that it would be necessary, on account of the contagious sickness which afflicted the city of Philadelphia, to convene the national legislature at some other place. This measure it was desirable to a void because it would occasion much public inconvenience and considerable public expense, and add to the calamities of the inhabitants of this city, whose sufferings must have excited the sympathy of all their fellow-citizens; therefore, after taking measures to ascertain the state and decline of the sickness, I postponed my determination, having hopes, now happily realized, that, without hazard to the lives or health of the members, Congress might assemble at this place, where it was next by law to meet. I submit, however, to your consideration whether a power to postpone the meeting of Congress, without passing the time fixed by the Constitution, upon such occasions, would not be a useful amendment to the law of 1794 ."

In the address of the House in response to the speech of the President, which it was at that time customary to make, the subject was noticed as follows :

"While our sympathy is excited by the recent sufferings of the citizens of Philadelphia, we participate in the satisfaction which you are pleased to express, that the duration of the late calamity was so limited as to render unnecessary the expense and inconvenience that would have been incident to the convention of Congress in another place, and we shall readily attend to every useful amendment to the law which contemplates the event of contagious sickness at the seat of government."
Congress does not seem, however, to have taken any action at this session.

During the summer of 1798 yellow fever again appeared, and this time it attained the proportions of a national scourge. It prevailed at Portsmouth, $\mathrm{N}$. H.; Boston and Salem, Mass.; Westerly, R. I.; Hartford, Stonington, New London and Norwalk, Conn.; New York; Bridgeton and Woodbury, N. J.; Philadelphia, Marcus Hook and Chester, Pa.; Wilmington, Christina, Duck Creek and New Castle, Del.; Baltimore, Md.; Norfolk, Petersburg and City Point, Va.; Charleston, S. C.

At the opening of the third session of the Fifth Congress, December 8, 1798, President Adams thus addressed the two Houses:

"While with reverence and resignation we contemplate the dispensation of Divine Providence in the alarming and destructive pestilence with which several of our cities and towns have been visited, there is cause for gratitude and mutual congratulations that the malady has disappeared, and that we are again permitted to assemble in safety at the seat of government for the discharge of our important duties. But when we reflect that this fatal disorder has within a few years made repeated ravages in some of our principal seaports, and with increased malignancy, and when we consider the magnitude of the evils arising from the interruption of public and private business, whereby the national interests are deeply affected, I think it my duty to invite the legislature of the Union to examine the expediency of establishing suitable regulations in aid of the health laws of the respective States; for, these being formed on the idea that contagious sickness may be communicated through the channels of commerce, there seems to be a necessity that Congress, who alone can regulate trade, should frame a system which, while it may tend to preserve the general health, may be compatible with the interests of commerce and the safety of the revenue."

Petitions were prepared to be laid before Congress, both in Philadelphia and New York, asking aid of the general government. The Philadelphia committee went so far as to propose non-intercourse with the West India ports during the dangerous months of the season. The New York committee objected to such stringent measures, and a modified memorial was adopted. The health officer of New York, Dr. Richard Bayley, urged the formation of quarantine establishments at a proper distance from seaport cities, where ships could be examined and, if necessary, thoroughly cleansed and disinfected.

The subject was again brought before Congress by Mr. Smith, of Maryland, who was now chairman of the Committee of Commerce, as appears from the following extract from the Annals of Congress:

“On Wednesday, January 23, 1799,Mr. Smith, of Maryland, from the Committee of Commerce, reported a bill respecting quarantine and heaIth laws, which was read and committed.

"On Monday, January 28, 1799, on motion of Mr. Smith, of Maryland, the House went into a committee of the whole, on the bill respecting quarantine and health laws; Mr. Rutledge in the chair.

"The bill was read as follows:

"Section 1. Be it enacted, etc., That the quarantine and other restraints which shall be required and established by the health laws of any State, or pursuant thereto, respecting any vessel arriving in, or bound to, any port or district thereof, whether from a foreign port or place, or from another district of the United States, shall be duly observed by the collectors, and all other officers of revenue of the United States, appointed and employed for the several collection districts of such States respectively, and by the masters and crews of the several revenue cutters, and by the military officers who shall command in any port or station upon the sea-coast; and all such officers of the United States shall be, and they hereby are, authorized and required faithfully to aid in the execution of such quarantine and health laws, according to their respective powers and precincts, and as they shall be directed from time to time by the Sec- 